\title{
Immunoelectron microscopic localization of small nuclear ribonucleoproteins and interchromatin granules in the 2-cell mouse embryo
}

\author{
V Baran 1, 2, I Melčák 2, J Otcovský 2, V Landa 3 \\ ${ }^{1}$ Institute of Animal Physiology, Slovak Academy of Sciences, 04001 Košice, \\ Palackého 12, Slovak Republic; \\ ${ }^{2}$ Institute of Experimental Medicine, Academy of Sciences of the Czech Republic, \\ 12800 Prague, Albertov 4; \\ ${ }^{3}$ Institute of Molecular Genetics, Academy of Sciences of the Czech Republic, \\ 14220 Prague, Vídeňská 1083, Czech Republic
}

(5th Franco-Czechoslovak Meeting, Jouy-en-Josas, December 1992)

\begin{abstract}
Summary - The distribution of U1, U2, U4, U5 and U6 small nuclear ribonucleoproteins (snRNPs) and interchromatin granules (IGs) was studied by electron-microscopic immunocytochemistry (EMI) in early 2-cell mouse embryos at the onset of embryonal transcription. The localization of these antigen structures was evaluated with respect to nucleoplasmic ribonucleoprotein (RPN) regions consisting of interchromatin and perichromatin areas. SnRNP structures of maternal origin (labelled with anti-Sm antibody) were widely distributed throughout the nucleoplasm. Specifically labelled IGs were detected by gold particle clusters distributed in the interchromatin regions of the nucleoplasm. Both immunodetections were negative in nucleolar precursor bodies (NPBs). In addition, the labelling of condensed chromatin blocks with anti-DNA antibody showed heterochromatin topology at this developmental stage. Small condensed chromatin blocks were distributed throughout the nucleus and also appeared in association with the NPB rim. The observed status quo represents a transient state of nuclear structure rearrangement.
\end{abstract}

mouse embryo / transcription onset / interchromatin granule / snRNP

Résumé - Localisation immunocytochimique sur coupes ultrafines de petites ribonucléoprotéines nucléaires et de granules interchromatiniens dans l'embryon de souris au stade 2 cellules. La distribution des petites ribonucléoprotéines nucléaires (snRNPs) U1, U2, U4, U5 et U6 et de granules interchromatiniens (IGs) a été étudiée par immunocytochimie en microscopie électronique dans des embryons de souris au stade 2 cellules au moment où la transcription embryonnaire commence. La localisation des structures antigéniques a été analysée par rapport à celle de régions riches en ribonucléoprotéines du noyau, les aires inter- et périchromatiniennes. Les snRNP d'origine maternelle (marquées avec l'anticorps anti-Sm) sont largement distribuées à travers le nucléoplasme. Les IGs détectés par des groupes de grains d'or sont localisés dans les régions interchromatiniennes. Les 2 types de marquage sont négatifs dans les précurseurs de nucléoles (NPBs). La topographie de l'hétérochromatine est donnée par le marquage avec un anticorps anti-ADN. De petits blocs de chromatine sont distribués dans tout le noyau et aussi à la périphérie des NPBs. L'image donnée par ces études représente un état transitoire de la structure nucléaire en réarrangement parallèle à la reprise de la transcription.

embryon de souris / début de la transcription / granules interchromatiniens / snRNPs 


\section{INTRODUCTION}

The 2-cell mouse embryo is characterized by a resumption of transcriptional activity and all classes of RNAs, including ribosomal RNA, are synthesized from this stage. In addition, the process of maternal mRNA degradation initiated during meiotic maturation continues in the 1 -cell stage (Clegg and Pikó, 1982, 1983; Payton et al, 1988). However, not all maternally derived RNA components are degraded simultaneously with maternal mRNA during transition from the 1-cell to the 2-cell stage. The ribosomal RNA content for example, decreases by only $\approx 25 \%$ during this interval (Pikó and Clegg, 1982; Telford et al, 1990). U1, U2, U4, U5 and U6 snRNAs present in oocytes are not degraded during the 1-cell stage and their contents remain relatively constant up to the blastocyst stage (Lobo et al, 1988; Dean et al, 1989). A somewhat similar situation was observed with U3 snRNA molecules (Prather et al, 1990), although synthesis and distribution of U3 snRNA and U3 snRNP follow a pattern independent of other major $U$ snRNPs and snRNAs. All the major snRNAs (U1, U2, U4, U5 and U6) involved in snRNP complexes are required for the generation of new mRNA molecules from primary transcripts or premRNA (Maniatis and Reed, 1987), while snRNP particles containing U3 snRNA are involved in the processing of pre-rRNA transcripts (for review Lührmann et al, 1990; Zieve and Sauterer, 1990; Lamond, 1991). The snRNAs and snRNPs primarily located in the germinal vesicle in preovulatory oocyte are released into the cytoplasm during germinal vesicle breakdown and subsequently relocalize in the pronuclei following fertilization and in the nuclei following the first cleaveage (Dean et al, 1989). Thus, pre-mRNA molecules synthesized at the time of transcriptional activation of the embryonic genome (2-cell stage of mouse embryo development) appear to be processed by snRNPs of maternal origin (Dean and Schultz, 1990; Watson et al, 1992). Intranuclear localization of $U$ snRNPs and/or interchromatin granules has been studied by EMI in other cell types (Fakan et al, 1984; Biggiogera et al, 1990; Raska et al, 1990, 1991, 1992; Spector, 1990; Vasquez-Nin et al, 1990) but not in mouse embryo. We studied therefore, the distribution of $\mathrm{U} 1, \mathrm{U} 2, \mathrm{U} 4, \mathrm{U} 5$ und $\mathrm{U} 6$ snRNP as revealed by anti-Sm antibody and the distribution of IGs with reference to localization of condensed chromatin blocks in mouse 2-cell stage of embryo at the time of transcriptional resumption.

\section{MATERIAL AND METHODS}

Female mice ( $\mathrm{F} 1$ hybrid-C57 BL6 $\times \mathrm{CBA}$ ) were superovulated by ip injection of $10 \mathrm{IU}$ of pregnant mare serum gonadotropin (Bioveta, Czechoslovakia) followed by 10 IU human chorionic gonadotropin (Léčiva, Czechoslovakia) 46-47 h later and mated with males of the same genetic origin. All 2-cell embryos were collected from the oviduct 35-42 $\mathrm{h}$ after hCG injection and immediately fixed in $2 \%$ paraformaldehyde and $0.2 \%$ glutaraldehyde mixture in $100 \mathrm{mM}$ phosphate buffer, $\mathrm{pH} 7.2$ for $60-90 \mathrm{~min}$ at $4^{\circ} \mathrm{C}$. A few embryos were frozen in liquid nitrogen in a mixture of $1.6 \mathrm{M}$ sucrose and $25 \%$ polyvinylpyrrolidone (Tokuyasu, 1989). The fibrin clot method was used for embedding embryos in pellets appropriate for cryoultramicrotomy (Raška, 1988). Immunolabelling was performed on thawed ultrathin cryosections placed on $\mathrm{Cu} / \mathrm{Pd} \mathrm{EM}$ grids covered with a carbon-Formvar film. Over fixed embryos were embedded in Lowicryl K4M resin (Serva, Heidelberg, Germany) following the standard procedure recommended by the producer. The embryos were embedded in agar blocks before dehydration (Janisch, 1974), permitting the good location of the embryo in the block. Lowicryl sections were labelled on $\mathrm{Cu} / \mathrm{Pd}$ EM grids covered with carbon-Formvar film. An indirect immunogold labelling procedure was used at room temperature. Grids were incubated with a monospecific human autoimmune serum with anti-Sm specificity (kindly provided by I 
Raskka, Prague) recognizing epitopes of common core protein moieties of U1, U2, U4, U5 and U6 snRNP particles (Lerner and Steitz, 1979). The serum was diluted with $5 \%$ foetal calf serum containing $500 \mu \mathrm{g} / \mathrm{ml}$ herring sperm DNA to adsorb traces of anti-DNA activity ( $\mathrm{Fa}$ kan et al, 1984). The mouse monoclonal antibody $3 \mathrm{C} 5$ (kindly provided by BM Turner, Birmingham, UK) against phosphoprotein components of interchromatin granules (IGs) was also used (Turner and Franchi, 1987). In addition, cryosections were incubated with mouse monoclonal antibody to DNA (Boehringer Co, Mannheim, Austria) specifically reacting with single- and double-stranded DNA molecules (Scheer et al, 1987). All primary antibodies were diluted in $5 \%$ foetal calf serum. After washing with phosphate-buffered saline (containing $0.05 \%$ Tween-20 for Lowicryl sections), bound antibodies were revealed with goat antihuman and goat anti-mouse $\operatorname{lgG}$, IgM secondary antibodies coupled to colloidal gold (5- or 10-nm particles; Janssen Life Science, Belgium) diluted $1: 25$ in $5 \%$ foetal calf serum. Lowicryl sections were incubated for 120 and $60 \mathrm{~min}$ and cryosections for 35 and $25 \mathrm{~min}$. Labelling specificity test were carried out by omitting the primary antibody and also by incubating sections with gold particles free of secondary antibody (for details of methods see Rask'ka, 1988; Tokuyasu, 1989; Roth et al, 1990).

\section{RESULTS}

The embryo cryosections provided a good ultrastructural picture of all cell compartments. NPBs, condensed chromatin blocks and nuclear membranes were well identified. Round NPBs had homogeneous appearance. The use of the anti-DNA antibody gave specific labelling on condensed chromatin blocks (fig 1). Labelled heterochromatin was distributed throughout the nucleus in the form of small patches. Significant labelling was observed in the NPB rim where labelled chromatin blocks appeared to be in close association with NPB. In contrast, the wide interchromatin spaces between heterochromatin clumps were devoid of gold particles. The absence of labelling in the space between these chromatin blocks reflected a very low local DNA concentration in these regions, possibly due to an extended conformation of topologically unfolded sequences and/or an actual absence of DNA (Scheer et al, 1987). Contrasted Lowicryl sections appeared to have lower contrast in comparision to cryosections.

U1 U2, U4, U5 and U6 snRNP recognized by the Sm autoantibody were distributed throughout the nucleoplasmic space (diffuse labelling pattern), except NPB and condensed heterochromatin (fig 2). However, the particles were visible in close association with heterochromatin blocks in the perichromatin space. $\mathrm{Sm}$ antigens were not concentrated within the IG areas but there was a heavy concentration of gold particles at the periphery of the IG clusters (fig 2a). The use of the antibody $3 \mathrm{C} 5$ against phosphoprotein components of interchromatin granules provided a positive signal in the whole nucleoplasm, except for the NPBs, but the overall (diffuse) labelling was much lower with respect to the Sm antibody (fig 3). However, many gold particles in the interchromatin space were found in clusters (fig 3, 3a). Gold particles were visible on the NPB outer layer but were not localized in the NPB rim (fig 3; compare DNA immunolocalization in this area).

\section{DISCUSSION}

The present study shows that U1, U2, U4, U5 and U6 snRNPs structures are widely distributed throughout the nucleoplasm and that interchromatin granules (IGs) were localized in clusters in the early 2-cell mouse embryo. Immunolabelling of IGs expressed by gold clusters was irregularly distributed throughout the nucleoplasm except in the NPB area. On the other hand, 


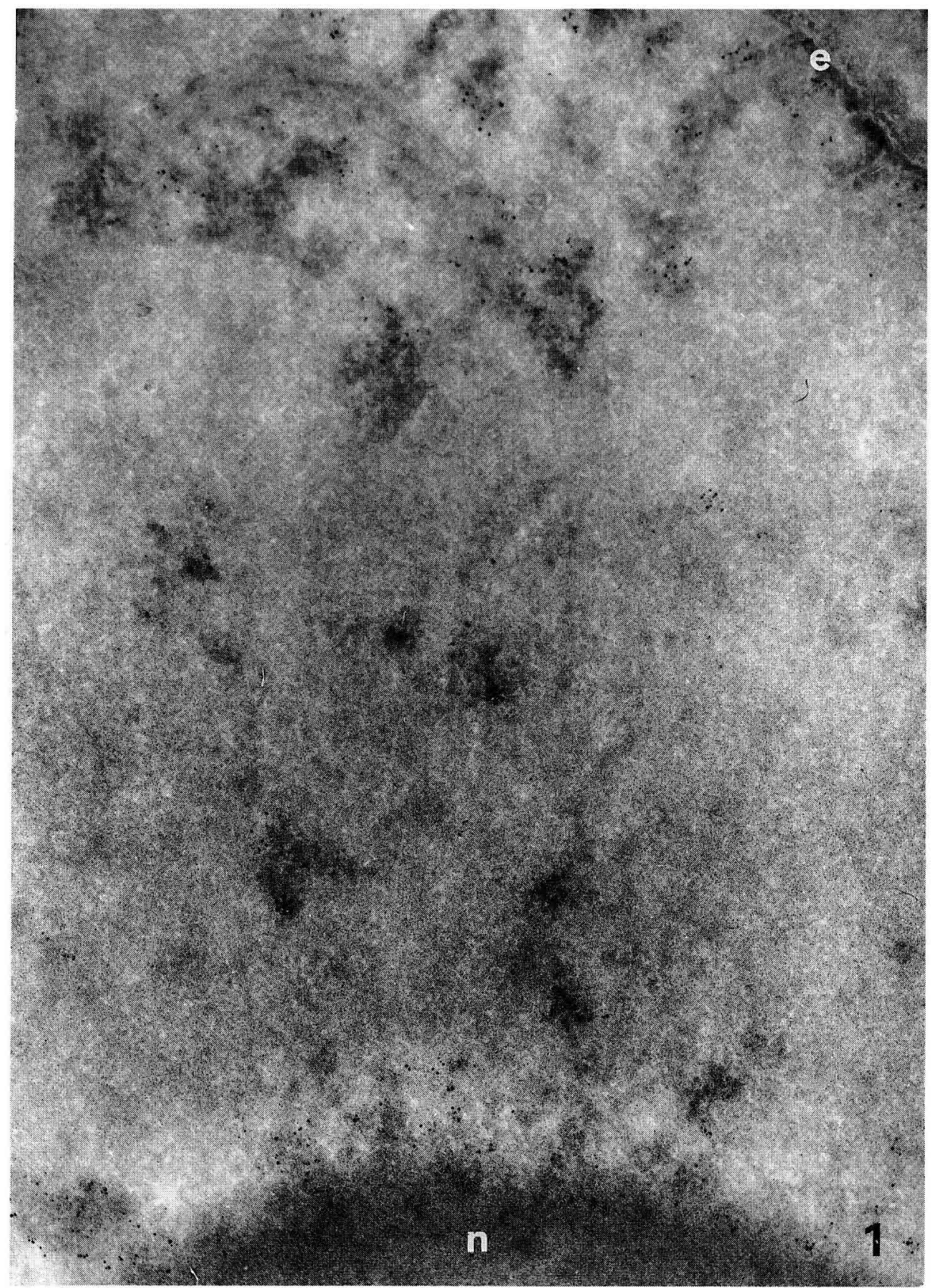

Fig 1. Cryosection of a 2-cell mouse embryo labelled with anti-DNA antibody. Gold particles are denser over blocks of condensed chromatin (stars). These heterochromatin blocks are distributed throughout the nucleus and associated with a nucleolar precursor body $(\mathrm{n})$. e : nuclear envelope; $x 52000$. 
the immunolabelling of Sm-antigen structures was more diffuse throughout the nucleoplasm. In this respect, our EMI data support earlier light microscopic immunocytochemical results showing snRNP particles, recognized by anti-Sm antibody concentrated on the outside of mouse zygote pronuclei and later found throughout the nucleoplasm. In 2-cell embryos the snRNPs were found in the whole nucleus except for the nucleolar regions (Dean et al, 1989; Prather et al, 1990). The relocalization of major $U$ snRNPs to pronuclei was also confirmed in bovine preimplantation embryo development (Watson et al, 1992). All $\mathrm{Sm}$ antigen structures in cultured somatic cells are localized in the nucleoplasmic RNP space and have been identified as perichromatin fibrils, perichromatin granules, interchromatin granules and nuclear bodies (Fakan et al, 1984; Raška et al, 1990). Interestingly, in coiled bodies a much greater concentration of "Sm" molecules is found than in IG clusters (Raška et al, 1990, 1991, 1992). In this respect, Raška et al (1992) did not observe high IG labelling with anti-Sm antibody as previously reported (Fakan, 1986). This result, which was shown in cultured cells (Raška et al, 1992), has been confirmed by our observation in 2-cell mouse embryos. In addition, perichromatin fibrils surrounding small clumps of condensed chromatin or dispersed throughout the interchromatin space were present in areas heavily labelled with anti-Sm antibodies. These fibrils represent extranucleolar RNP structures containing newly synthesized premRNA and perichromatin granules for storage and/or transport of the nuclear RNA (Fakan and Odartchenko, 1980). In this context, clusters of IGs detected by electron microscopic autoradiography indicated the presence of very stable RNA (Fakan, 1986). On the basis of the widespread immunolocalization of $\mathrm{Sm}$ antigens (core proteins of U1, U2, U4, U5 and U6 snRNP) we assume that proteins of major $U$ snRNP are present in various domains of nucloeplasmic RNP space and that they are not enriched within the IG cluster areas. It is possible that IGs are pre-assembly sites of spliceosomal structures (see Carmo-Fonseca et al, 1991). EMI localization of snRNP has been carried out recently in preimplantation bovine embryos using antiSm antibody (Kopečný et al, 1991). In 8cell cow embryos at the onset of transcription, labelling was markedly concentrated at the borderline of condensed chromatin blocks, where it was mainly associated with perichromatin fibrils. Before the onset of transcription at the 2-cell and 4-cell stage, diffuse labelling was seen in the nucleoplasm. In comparison with the results of the present study, interchromatin granules were more labelled (Kopečný et al, 1991). It seems that a correlation exists between reactivation of embryonal transcription and structural redistribution of DNA and other participating molecules. DNA originally localized at the periphery of the nuclei moves toward the interior (Kopečný et al, 1989a). Blocks of condensed chromatin are formed at the onset of transcription (Kopečný et al, 1989b). In fact, the diffuse nuclear distribution of snRNP at earlier stage of embryo development and the subsequent association of snRNPs with the borderline of the condensed chromatin provides evidence of the relationship between chromatin restructuration and the onset of transcription. On the other hand, it is possible that a redistribution of snRNP structures takes place to form a nuclear reticulum (Carmo-Fonseca et al, 1991), before the onset of embryonal extranucleolar transcription. It should be noted that the antibody to a non-snRNP splicing factor SC35 (Fu and Maniatis, 1990) generates at the ultrastructural level an identical labelling pattern in cultured cells as does the $3 \mathrm{C} 5$ antibody (Raška, personal communication). SC35 belongs to the 
SR protein family (Roth et al, 1991) and IG phosphoproteins targeted by the 3C5 antibody apparently belong to the same protein family (Raška, personal communication).

\section{ACKNOWLEDGMENTS}

This work was supported by a grant $61 / 91$ from the Slovak Academy of Sciences.

\section{REFERENCES}

Biggiogera M, Fakan S, Leser G, Martin TE, Gordon J (1990) Immunoelectron microscopical visualization of ribonucleoproteins in the chromatoid body of mouse spermatids. Mol Reprod Dev 16, 150-158

Carmo-Fonseca $M$, Tollervey D, Pepperkok R, Barabino SML, Merdes A, Brunner C, Zamore PD, Green M, Hurt E, Lamond Al (1991) Mammalian nuclei contain foci which are highly enriched in components of premRNA splicing machinery. EMBO J 10, 195 . 206

Clegg KB, Pikó L (1982) RNA synthesis and cytoplasmic polyadenylation in the 1-cell mouse embryo. Nature (Lond) 295, 342-345

Clegg KB, Pikó L (1983) Quantitative aspects of RNA synthesis and polyadenylation in 1-cell and 2-cell mouse embryos. J Embryol Exp Morphol 74, 169-182

Dean WL, Seufert AC, Schultz GA, Prather RS, Simerly C, Schatten G, Pilch DR, Marzluff WF (1989) The small nuclear RNAs for pre-
mRNA splicing are coordinately regulated during oocyte maturation and early embryogenesis in the mouse. Development 106, 325-334

Dean WL, Schultz AC (1990) Relocalization of small ribonucleoprotein particles (snRNPs) during the cell cycle of mouse embryo developement is independent of RNA synthesis, DNA synthesis and cytokinesis. Cell Differ Dev 31, 43-51

Fakan S (1986) Structural support for RNA synthesis in the cell nucleus. Methods Achiev Expt/ Pathol 12, 105-140

Fakan S, Odartchenko N (1980) Ultrastructural organization of the cell nucleus in early mouse embryos. Biol Cell 37, 211-218

Fakan S, Leser G, Martin TE (1984) Ultrastructural distribution of nuclear ribonucleoproteins as visualized by immunocytochemistry on thin sections. J Cell Biol 98, 358-363

Fu XD, Maniatis T (1990) Factor required for mammalian spliceosome assembly is localized to discrete regions in the nucleus. $\mathrm{Na}$ ture (Lond) 343, 437-441

Janisch R (1974) Oriented embedding of singlecelled organisms. Stain Technol 49, 157-160

Kopečný, Fulka J, Pivko J, Petr J (1989a) Localization of replicated-DNA containing sites in preimplantation bovine embryo in relation to the onset of RNA synthesis. Biol Cell 65, 231-238

Kopečný V, Fléchon JE, Camous S, Fulka J Jr (1989b) Nucleologenesis and the onset of transcription in the 8-cell bovine embryo : fine structural autoradiography study. Mol Reprod Dev 1, 79-90

Kopečný V, Fakan S, Pavlok A, Pivko J, Grfenau $P$, Biggiogera $M$, Leser $G$, Martin TE (1991) Immunoelectron microscopic localiza-

Fig 2. Lowicryl section of a 2-cell mouse embryo labelled with anti-Sm antibody (revealing the distribution of U1, U2, U4, U5 and U6 snRNP) in the whole nucleoplasm as diffuse labelling pattern except the nucleolar precursor body (n). Stars: condensed chromatin blocks; c: cytoplasm; x 34000 . a. The clusters of interchromatin granules (rings) were not labelled by anti-Sm antibody. Gold particles, however, are found at the periphery of the cluster of interchromatin granules; $x: 78000$.

Fig 3. Immunolocalization of interchromatin granules (Lowicryl section) with $3 \mathrm{C} 5$ antibody in a 2-cell mouse embryo. Many gold particles are found in clusters (stars) localized in whole nucleoplasm, except the nucleolar precursor body (n). Double star: condensed heterochromatin blocks; arrows: perinucleolar rim; arrowheads: perinucleolar shell: $\times 28000$. a. A detailed picture of the immunolocalization of antigens recognized by $3 \mathrm{C} 5$ antibody (ring); $n$ : nucleolar precursor body; $x 75000$. 
tion of small nuclear ribonucleoproteins during bovine early embryogenesis. Mol Reprod Dev 29, 209-219

Lamond Al (1991) Nuclear RNA processing. Curr Opin Cell Biol 3, 493-501

Lerner MR, Steitz JA (1979) Antibodies to small nuclear RNAs complexed with proteins are produced by patients with systemic lupus erythematosus. Proc Natl Acad Sci USA 76, 5495-5499

Lobo SM, Marzluff WF, Seufert AC, Dean WL, Schultz GA, Simerly C, Schatten G (1988) Localization and expression of U1 RNA in early mouse embryo development. Dev Biol 127, 349-361

Lührmann R, Kaster B, Bach M (1990) Structure of spliceosomal snRNPs and their role in pre-mRNA splicing. Biochim Biophys Acta 1087, 265-292

Maniatis T, Reed R (1987) The role of small nuclear ribonucleoprotien particles in premRNA splicing. Nature (Lond) 325, 673-678

Payton BV, Rempel R, Bachvarova R (1988) Changes in state of adenylation and time of degradation of maternal mRNAs during oocyte maturation and early embryonic development in the mouse. Dev Biol 129, 304

Pikó L, Clegg KB (1982) Quantitative changes in total RNA, total poly $(A)$ and ribosomes in early mouse embryos. Dev Bio/ 89, 362-378

Prather R, Simerly C, Schatten G, Pilch DR, Lobo SM, Marzluff WF, Dean WL, Schultz GA (1990) U3 snRNP and nucleolar development during oocyte maturation, fertilization and early embryogenesis in the mouse: U3 snRNA and snRNPs are not regulated coordinate with other snRNAs and snRNPs. Dev Biol 138, 247-255

Raška I (1988) Electron Microscopic Immunocytochemistry with Colloidal Gold. A Laboratory Manual of the Practical Course. Institute of Experimental Medicine, Prague, 1-110

Raška I, Ochs RL, Salamnie-Michel L (1990) Immunocytochemistry of the cell nucleus. Electron Microsc Rev 3, 301-353

Raška I, Andrade LEC, Ochs RL, Chan EKL, Chang CM, Roos G, Tan EM (1991) Immunological and ultrastructural studies of the nuclear coiled body with autoimmune antibodies. Exp Cell Res 195, 27-37

Raška I, Dundr M, Koberna K (1992) Structurefunction subcompartments of the mammalian cell nucleus as revealed by the electron microscopic affinity cytochemistry. Cell Biol Int Rep 16, 771-789

Roth J, Taatjes DJ, Tokuyasu KT (1990) Contrasting of Lowicryl K4M thin section. Histochemistry 95, 123-126

Roth MB, Zahler AM, Stolk JA (1991) A conserved family of nuclear phosphoproteins localized to sites of polymerase II transcription. J Cell Biol 115, 587-596

Scheer U, Messner K, Hazan R, Raska I, Hausmann P, Falk $H$, Spiess E, Franke WW (1987) High sensitivity immunolocalization of double and single-stranded DNA by a monoclonal antibody. Eur J Cell Biol 43, 358-371

Spector DL (1990) Higher order nuclear organization. Three-dimensional distribution of small nuclear ribonucleoprotein particles. Proc Natl Acad Sci USA 87, 147-151

Telford NA, Watson AJ, Schultz GA (1990) Transition from maternal to embryonic control inearly mammalian development : a comparison of several species. Mol Reprod Dev 26, 90-100

Tokuyasu KT (1989) Use of poly(vinylpyrrolidone) and poly(vinylalcohol) for cryoultramicrotomy. Histochem J 21, 163-171

Turner BM, Franchi L (1987) Identification of protein antigens associated with clusters of interchromatin granules in both interphase and mitotic cells. J Cell Sci 87, 269-282

Vasquez-Nin GH, Echeverria OM, Fakan S, Leser G, Martin TE (1990) Immunoelectron microscope localization of snRNPs in the polytene nucleus of salivary glands of Chironomus thummi. Chromosoma 99, 44-51

Watson AJ, Wiemer KE, Arcellana-Panlilio $M$, Scultz GA (1992) U2 small nuclear RNA localization and expression during bovine preimplantation development. Mol Reprod Dev $31,231-240$

Zieve GW, Sauterer RA (1990) Cell biology of the snRNP particles. Biochem Molec 25, 146 